\title{
Immunoglobulins in the cerebrospinal fluid of patients with late syphilis
}

\author{
MIECZYSŁAW GIBOWSKI AND TATIANA MACHOŃKO \\ From the Dermatology Clinic, Institute of Nervous System and Sensory Organ Diseases, Medical \\ Academy, Poznan, Poland
}

SUMMARY The concentrations of immunoglobulins $\mathrm{G}, \mathrm{A}$, and $\mathrm{M}$ were measured in 62 samples $\stackrel{\frac{\rho}{?}}{=}$. of cerebrospinal fluid from 35 patients with asymptomatic neurosyphilis, 18 with symptomatic iv neurosyphilis, and nine with late syphilis of other organs. The most frequent and highest increase.in IgG and IgA occurred in patients with symptomatic neurosyphilis. IgM was found in only five $\tilde{O}^{\circ}$ patients, but its presence, together with an increase in IgG and IgA concentrations, appears to음 indicate activity of the pathological process and a poor prognosis for the course of the disease.

\section{Introduction}

The behaviour of immunoglobulins in the cerebrospinal fluid (CSF) in patients with syphilis always arouses great interest. The purpose of the present investigation was to determine whether or not the central nervous system (CNS) was infected with Treponema pallidum and, if so, to determine the stage of the infection and the characteristics of the immunoglobulin pattern that might indicate activity of the pathological process.

Many authors have investigated the presence of specific antitreponemal antibodies in the CSF by immunofluorescence methods using labelled polyspecific and mono-specific antisera. ${ }^{1-7}$ Some authors have determined the total immunoglobulin concentrations by immunodiffusion methods. ${ }^{4-8}$ The results of these investigations have not always agreed, but some investigators stress the fact that in some patients with syphilis the CSF shows the presence of IgM and $\operatorname{IgA}$, often with a high concentration of IgG. This is thought to prove active treponemal infection of the CNS.

The aim of our work was to observe the behaviour of immunoglobulins in the CSF of patients with late syphilis and to determine whether or not there was a correlation between the immunoglobulin concentrations in the CSF and the type of syphilis and its activity.

\footnotetext{
Address for reprints: Dr $\mathbf{M}$ Gibowski, Instytut Chorób Ukladu Nerwowego i Narzadów Zmyslow AM u Poznaniu, Klinika Dermatolgii, 60-355 Poznán, ul Przybyszewskiego 49, Poland

Accepted for publication 8 August 1980
}

\section{Patients and methods}

STUDY POPULATION

Between 1975 and 1979 samples of CSF from $62 \stackrel{\infty}{-}$ patients (44 men and 18 women) with late syphilis, aged between 24 and 74 years, were examined. Thirty-five patients had asymptomatic neurosyphilis and 18 had symptomatic neurosyphilis (four, tabes dorsalis; six, vascular neurosyphilis; five, general paresis; two, meningovascular syphilis; and one, $\overrightarrow{\vec{\overrightarrow{ }}}$ tabo-paresis). Nine patients had late syphilis of other $\frac{3}{3}$ organs (three, syphilitic gummata, and six, cardiovascular syphilis). All but nine of the patients had been treated previously (two with asymptomatic neurosyphilis, four with symptomatic neurosyphilis, and three with late syphilis of other organs). ${ }^{*}$ The interval between the last treatment and examination of the CSF varied from three to 29 years.

\section{DIAGNOSIS}

Neurosyphilis was diagnosed on the basis of $\frac{D}{2}$ examination of the CSF; the results of serological tests for syphilis, protein content, cell count, results $N$ of the Pandy, Nonne-Apelt, and Lange's colloidal gold tests, together with the results of clinical neurological examinations, were taken into account.

*Until 1956 the obligatory treatment of late syphilis recommended by the Ministry of Health was with $4 \cdot 2$ megaunits of procaine penicillin, 300000 -unit doses daily for 14 days, and between one and $\mathscr{D}$ four courses of arsenic and bismuth. Since 1960 the obligatory treatment consisted only of penicillin, procaine penicillin 18 megaunits in 600000 -unit doses or eight injections of 1.2 megaunits of $\bar{O}$ benzathine penicillin given every fifth day. Since 1974 the $\overparen{D}$ recommended treatment is with procaine penicillin 36 megaunits, in $\frac{\rho}{T}$ $1 \cdot 2$-megaunit doses, or benzathine penicillin 48 megaunits, in 1-2-megaunit doses, every fourth day. 
Syphilis of other organs was diagnosed on the basis of serological tests for syphilis, additional laboratory examinations, and clinical findings.

\section{SEROLOGICAL TESTS}

All samples of CSF and serum were examined by the following serological tests: the qualitative fluorescent treponemal antibody-absorbed (FTA-ABS) test; the quantitative fluorescent treponemal antibody (FTA) test; the $T$ pallidum haemagglutination assay (TPHA); the $T$ pallidum immobilisation (TPI) test; the Venereal Disease Research Laboratory (VDRL) test; and Kolmer's test. The FTA-ABS, FTA, TPI, VDRL, and Kolmer's tests were carried out by the methods routinely applied in Poland and described in detail by Lesinski et al. ${ }^{10}$ The TPHA was carried out by the modified method described by ManikowskaLesinska et al. ${ }^{11}$ General examinations of the CSF were carried out by the methods described by Pawelski and Maj. ${ }^{12}$

\section{CSF VALUES}

The normal limits of the cell count were taken to be from 0 to $5 \times 10^{6} / 1$ (from 0 to $5 / \mu \mathrm{l}$ ) and the normal protein content as $0 \cdot 16-0 \cdot 36 \mathrm{~g} / \mathrm{l}(16-36 \mathrm{mg} / 100 \mathrm{ml})$. The immunoglobulin concentration in the CSF was measured by the radial diffusion method in agar gel according to Mancini ${ }^{4}$; the determinations were made on Partigen plates (Behringwerke).

\section{CONTROL SAMPLES}

The control samples consisted of 50 specimens of CSF from non-syphilitic patients attending the neurological and neurosurgical department in whom general examinations of the CSF did not show any variations from normal limits. In this group IgG was present in all samples (table I); IgA was present in $16 \%$ of samples (table I). The accepted upper admissible concentration of $\operatorname{IgA}$ in the CSF was $0.003 \mathrm{~g} / 1(0.25 \mathrm{mg} / 100 \mathrm{ml}) ; 96 \%$ of control samples had concentrations below this level. IgM was not found in any of the $\mathbf{5 0}$ control samples.

\section{Results}

The results of the determinations of the immunoglobulin concentrations in 62 patients with late syphilis and in the control group are given in figs 1 and 2 and in tables I-III.

\section{IMMUNOGLOBULIN G}

IgG was present in the CSF of all patients (table I and fig 1). The highest IgG concentrations in the group of patients with symptomatic neurosyphilis occurred in those with vascular neurosyphilis and with general paresis (table I).

\section{IMMUNOGLOBULIN A}

IgA was found in $37(59 \cdot 7 \%)$ patients (table I and fig 2); it was present in $21(60 \%)$ patients with asymptomatic neurosyphilis (table I). Of the 18 patients with symptomatic neurosyphilis, IgA was present in $12(67 \%)$. In the group of nine patients with late syphilis of other organs IgA was found in five $(56 \%)$.

\section{IMMUNOGLOBULIN M}

IgM was present in only five of the 62 patients (one with asymptomatic neurosyphilis and four with symptomatic neurosyphilis; table II). These five patients also had high concentrations of IgG $(0 \cdot 074-0.35 \mathrm{~g} / \mathrm{l} ; 7 \cdot 4-35 \mathrm{mg} / 100 \mathrm{ml})$ and of IgA $(0.018-0.048 \mathrm{~g} / 1 ; 1 \cdot 8-4 \cdot 8 \mathrm{mg} / 100 \mathrm{ml})$ in the CSF. They also showed great variations in general CSF findings (increased pleocytosis, increased total

TABLE I Concentrations of $\operatorname{Ig} G$ and $\operatorname{Ig} A$ in 62 patients with syphilis and 50 controls

\begin{tabular}{|c|c|c|c|c|c|c|}
\hline \multirow[b]{3}{*}{ Diagnosis } & \multicolumn{6}{|c|}{ Immunoglobulin concentrations $(g / l)$ in $C S F$} \\
\hline & \multicolumn{3}{|l|}{$\operatorname{Ig} G$} & \multicolumn{3}{|l|}{$\operatorname{Ig} A$} \\
\hline & No of patients & Mean & Range & $\begin{array}{l}\text { No of patients } \\
(\%)\end{array}$ & Mean & Range \\
\hline Asymptomatic neurosyphilis & 35 & 0.056 & $0 \cdot 016-0 \cdot 17$ & $21(60)$ & 0.006 & $0-0 \cdot 044$ \\
\hline Symptomatic neurosyphilis & 18 & 0.099 & $0 \cdot 015-0.35$ & $12(67)$ & 0.011 & $0-0.048$ \\
\hline Tabes dorsalis & 4 & $0 \cdot 038$ & & & 0.005 & \\
\hline Vascular syphilis & 6 & $0 \cdot 177$ & & & 0.015 & \\
\hline General paresis & 5 & 0.092 & & & 0.017 & \\
\hline Meningovascular syphilis & 2 & 0.059 & & & 0 & \\
\hline Tabo-paresis & 1 & $0 \cdot 022$ & & & 0.003 & \\
\hline Late syphilis of other organs & 9 & 0.038 & $0 \cdot 013-0 \cdot 075$ & $5(56)$ & 0.004 & $0-0.013$ \\
\hline Gummata & 3 & 0.047 & & & 0.004 & \\
\hline Cardiovascular & 6 & 0.034 & & & 0.004 & \\
\hline Control group & 50 & 0.033 & $0.004-0 \cdot 062$ & $8(16)$ & 0.0004 & $0-0.005$ \\
\hline
\end{tabular}

Conversion: SI to traditional units-Immunoglobulin concentration: $1 \mathrm{~g} / \mathrm{l} \approx 100 \mathrm{mg} / 100 \mathrm{ml}$ 
TABLE II Concentrations of IgM in the CSF of five patients with syphilis

\begin{tabular}{lllll}
\hline Diagnosis & $n$ & $\begin{array}{l}\text { No of } \\
\text { patients } \\
\text { with IgM }\end{array}$ & Concentration $(g / l)$ & $\begin{array}{l}\text { Previous } \\
\text { treatment }\end{array}$ \\
\hline $\begin{array}{l}\text { Asymptomatic } \\
\text { neurosyphilis }\end{array}$ & 35 & 1 & $0 \cdot 18$ & Treated \\
$\begin{array}{l}\text { Symptomatic } \\
\text { neurosyphilis }\end{array}$ & 18 & 1 & $0 \cdot 03$ & \\
Vascular neurosyphilis & & 1 & $\begin{array}{l}0.02 \\
0.21\end{array}$ & $\begin{array}{l}\text { Untreated } \\
\text { Untreated } \\
\text { General paresis }\end{array}$ \\
\hline
\end{tabular}

TABLE III Correlation of protein concentration and cell count with CSF immunoglobulin concentrations in 62 patients with late syphilis and in 50 controls

\begin{tabular}{|c|c|c|c|c|c|}
\hline \multirow[b]{2}{*}{ Protein } & \multirow[b]{2}{*}{ Cell count } & \multirow[b]{2}{*}{ No of patients } & \multicolumn{3}{|c|}{ Mean and standard deviation $(g / l)$} \\
\hline & & & $I g G$ & $\operatorname{Ig} A$ & $I g M$ \\
\hline \multicolumn{6}{|l|}{$\begin{array}{l}\text { Patients with } \\
\text { late syphilis (62): }\end{array}$} \\
\hline $\begin{array}{l}\text { Normal* } \\
\text { Raised }\end{array}$ & $\begin{array}{l}\text { Normalt } \\
\text { Raised } \\
\text { Raised }\end{array}$ & $\begin{array}{l}29 \\
33 \\
33 \\
29 \\
14\end{array}$ & $\begin{array}{l}0.055 \pm 0.044 \\
0.071 \pm 0.07 \\
0.046 \pm 0.036 \\
0.086 \pm 0.077 \\
0.12 \pm 0.095\end{array}$ & $\begin{array}{l}0.005 \pm 0.007 \\
0.009 \pm 0.011 \\
0.003 \pm 0.003 \\
0.013 \pm 0.014 \\
0.019 \pm 0.015\end{array}$ & $\begin{array}{l}0 \cdot 0007 \pm 0.004 \\
0 \cdot 003 \pm 0 \cdot 007 \\
0 \cdot 0006 \pm 0.004 \\
0 \cdot 003 \pm 0.008 \\
0 \cdot 006 \pm 0 \cdot 01\end{array}$ \\
\hline $\begin{array}{l}\text { Raised } \\
\text { Control group (50): }\end{array}$ & Raised & 14 & $0 \cdot 12 \pm 0 \cdot 095$ & $0 \cdot 019 \pm 0 \cdot 015$ & $0 \cdot 006 \pm 0 \cdot 01$ \\
\hline Normal* & Normalt & 50 & $0.033 \pm 0.013$ & $0 \cdot 0004 \pm 0 \cdot 0013$ & 0 \\
\hline
\end{tabular}

*Normal protein concentration $=0 \cdot 16-0 \cdot 36 \mathrm{~g} / \mathrm{l}(16-36 \mathrm{mg} / 100 \mathrm{ml})$

tNormal cell count $=0-5 \times 106 / 1\left(0-5 / \mathrm{mm}^{3}\right)$

FIG 1 Concentration of IgG in cerebrospinal late syphilis.

Conversion: traditional to SI unitsimmunoglobulin concentra tion: $100 \mathrm{mg} / 100 \mathrm{ml}$ $\approx 1 \mathrm{~g} / \mathrm{l}$

\section{Late syphilis of other organs}


protein content, and positive results to globulin tests) and an FTA test titre in the CSF which ranged from $1 / 100$ to $1 / 200$.

Two basic indicators of neurosyphilitic activityraised protein content and pleocytosis-compared with the concentrations of the three immunoglobulin classes in 62 patients with late syphilis are given in table III. There was a marked correlation between the increase in mean immunoglobulin concentrations and the increase in total protein as well as in pleocytosis in the CSF. This correlation was most pronounced in patients in whom both the cell count and protein content were increased.

\section{Discussion}

Our investigations showed that the mean and individual concentrations of IgG in samples of CSF were higher and occurred most often in patients with symptomatic neurosyphilis. The highest concentrations were found in patients with vascular neurosyphilis followed by those with general paresis. The mean IgG concentration was also noticeably higher in patients with asymptomatic neurosyphilis than in the control samples. On the other hand, the results in patients with late syphilis of other organs differed least from those in the control group.

These observations agree with those of Bowszyc, ${ }^{4}$ Heitmann, ${ }^{5}$ and Kolar and Bukhart, ${ }^{6}$ who also found high concentrations of IgG in patients with neurosyphilis.

IgA was present in about $60 \%$ of the patients examined compared with only $16 \%$ of the control group. The mean IgA concentration in all groups of patients with syphilis was higher than in the control group, but, as with IgG, the highest mean concentration of IgA was found in patients with symptomatic neurosyphilis (in patients with meningovascular syphilis and with general paresis) followed by those with asymptomatic neurosyphilis and then those with late syphilis of other organs.

Although it is commonly accepted that antitreponemal antibodies of the IgA class play a small part in infection with syphilis, the evident increase of the IgA concentration in the CSF suggests that we are dealing with a specific type of immunological response connected with infection of the CNS. This may be a response to antigens released as a result of

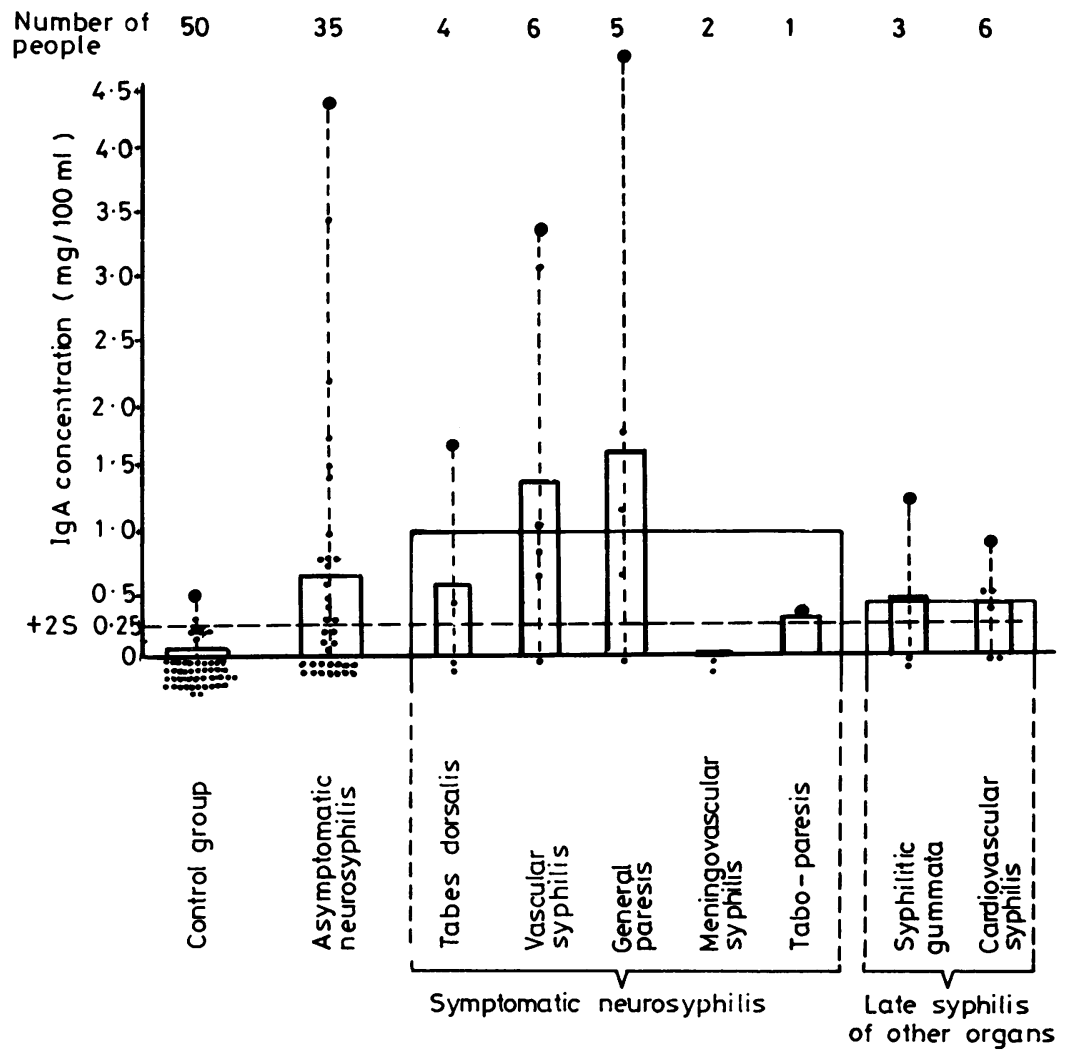

FIG 2 Concentration of $\operatorname{Ig} A$ in cerebrospinal fluid of 62 patients with late syphilis. Conversion: traditional to SI units-immunoglobulin concentration: $100 \mathrm{mg} / 100 \mathrm{ml}$ $\approx 1 \mathrm{~g} / \mathrm{l}$. 
the damage caused to the CNS by micro-organisms. Similar suggestions were also put forward by Leclerc et al. ${ }^{7}$

We found IgM in the CSF, but its presence in the CSF of patients with late syphilis is a rare phenomenon; IgM was detected in only five patients. Bowszyc ${ }^{4}$ also found IgM in the CSF of only a few patients with neurosyphilis, in whom there was also a high concentration of IgG. Oxelius et al, ${ }^{8}$ examining samples of CSF from patients with untreated neurosyphilis, found IgM and suggested its local production and its importance in the evaluation of activity of the pathological process. Kolar and Bukhart, ${ }^{6}$ who used immunoelectrophoresis, did not find any IgM in the CSF of patients with neurosyphilis; they ascribed their results to previous treatment of the patients they studied.

We also consider that previous treatment is the direct reason why IgM is found so rarely in the CSF. In our study population most patients had already been treated and most probably did not have an active infection of the CNS when investigated. We believe, therefore, that the finding of IgM in the CSF-which often occurs in association with high concentrations of $\operatorname{IgG}$ and $\operatorname{IgA}$-could indicate an active pathological process. This theory is also supported by the general changes found in the CSF and may be important in evaluating the effectiveness of treatment and in detecting possible failures of treatment to arrest activity.

\section{References}

1. Duncan WP, Jenkins TW, Parham CE. Fluorescent treponemal antibody cerebrospinal fluid (FTA-CSF) test. $\mathrm{Br} J$ Vener Dis 1972; 48:97-101.

2. Duncan WP, Kuhn USG. Further studies of the fluorescent treponemal antibody cerebrospinal fluid (FTA-CSF) test with a monospecific anti-IgM conjugate. Br J Vener Dis 1973;49. 478-90.

3. Wilkinson AE. Fluorescent treponemal antibody test on cerebrospinal fluid. Br J Vener Dis 1973;49:346-9.

4. Bowszyc J. Zachowanie się płynu mózgowo-rdzeniowego w kile $w$ aspekcie badań immunologicznych. (The behaviour of cerebrospinal fluid in syphilis in the aspect of immunological investigations). Przegl Dermatol 1975;3:365-71.

5. Heitmann HJ. Quantitative Bestimmung der Immunoglobuline (IgG) im Liquor cerebrospinalis bei der Lues mit und ohne Beteiligung des Nervensystems. Hautarzt 1972; 1:31-3.

6. Kolar OJ, Bukhart JE. Neurosyphilis. Br J Vener Dis 1977; 53:221-5.

7. Leclerc G, Giroux M, Birry A, Kasatiya S. Study of fluorescent treponemal antibody test on cerebrospinal fluid using monospecific anti-immunoglobulin conjugates IgG, IgM and IgA. Br J Vener Dis 1978;54:303-8.

8. Oxelius VA, Rorsman H, Laurell AB. Immunoglobulin of cerebrospinal fluid in syphilis. Br J Vener Dis 1969;2:121-5.

9. Mancini G, Carbonara AO, Heremans JF. Immunochemical quantitation of antigens by single radial immunodiffusion. Immunochemistry 1965; 2:235-41.

10. Lesiński J, Miedziński F, Towpik J. Modern Syphilology. 1st ed. Warsaw: Polish State Medical Edition, 1970.

11. Manikowska-Lesińska W, Linda B, Szymska K. Studies on the method of the TPHA test. Przegl Dermatol 1975;62:663-9.

12. Pawelski S, Maj S. Standards and Clinical Interpretation of Diagnostic Examinations in Internal Medicine. 1st ed. Warsaw: Polish State Medical Edition, 1971. 